Article

\title{
Evaluation of Controlled Release Urea on the Dynamics of Nitrate, Ammonium, and Its Nitrogen Release in Black Soils of Northeast China
}

\author{
Xin Tong, Xueqin He, Hongwei Duan, Lujia Han and Guangqun Huang * \\ Laboratory of Biomass \& Bioprocessing Engineering, College of Engineering, China Agricultural University, \\ (East Campus), Beijing 100083, China; tong2012@cau.edu.cn (X.T.); hxq12@cau.edu.cn (X.H.); \\ dhwsg123@cau.edu.cn (H.D.); hanlj@cau.edu.cn (L.H.) \\ * Correspondence: huanggq@cau.edu.cn; Tel.: +86-10-6273-6778
}

Received: 17 November 2017; Accepted: 3 January 2018; Published: 11 January 2018

\begin{abstract}
Controlled release urea (CRU) is considered to enhance crop yields while alleviating negative environmental problems caused by the hazardous gas emissions that are associated with high concentrations of ammonium $\left(\mathrm{NH}_{4}{ }^{+}\right)$and nitrate $\left(\mathrm{NO}_{3}{ }^{-}\right)$in black soils. Short-term effects of sulfur-coated urea (SCU) and polyurethane-coated urea (PCU), compared with conventional urea, on $\mathrm{NO}_{3}{ }^{-}$and $\mathrm{NH}_{4}{ }^{+}$in black soils were studied through the buried bag experiment conducted in an artificial climate chamber. We also investigated nitrogen $(\mathrm{N})$ release kinetics of CRU and correlations between the cumulative $\mathrm{N}$ release rate and concentrations of $\mathrm{NO}_{3}{ }^{-}$and $\mathrm{NH}_{4}{ }^{+}$. CRU can reduce concentrations of $\mathrm{NO}_{3}{ }^{-}$and $\mathrm{NH}_{4}{ }^{+}$, and $\mathrm{PCU}$ was more effective in maintaining lower soil $\mathrm{NO}_{3}{ }^{-} / \mathrm{NH}_{4}{ }^{+}$ratios than $\mathrm{SCU}$ and $\mathrm{U}$. Parabolic equation could describe the kinetics of $\mathrm{NO}_{3}{ }^{-}$and $\mathrm{NH}_{4}{ }^{+}$treated with PCU. The Elovich equation could describe the kinetics of $\mathrm{NO}_{3}{ }^{-}$and $\mathrm{NH}_{4}{ }^{+}$treated with SCU. The binary linear regression model was established to predict $\mathrm{N}$ release from PCU because of significant correlations between the cumulative $\mathrm{N}$ release rate and concentrations of $\mathrm{NO}_{3}{ }^{-}$and $\mathrm{NH}_{4}{ }^{+}$. These results provided a methodology and data support for characterizing and predicting the $\mathrm{N}$ release from PCU in black soils.
\end{abstract}

Keywords: black soils; controlled release urea; nitrate; ammonium; kinetics; correlation

\section{Introduction}

Mollisols are known in other soil classification systems as "black soils" in China. Generally, there are four main major regions of Mollisols on a world-wide basis. The eastern belt among them is best represented in northeast China [1]. Black soils in northeast China are universally known for their good natural fertility and are good for food production [2,3]. In the next 10-15 years, the northeast region is expected to increase China's grain production by $50 \%$ [4,5]. In addition, their physical and chemical properties are far superior when compared with other soils $[3,6]$. However, over the past few decades, large amounts of chemical fertilizers have been excessively used for increasing crop yields to meet the growing demand for food [7-10]. Urea, an important synthetic fertilizer, is widely used all over the world as the main source of plant nutrition [11-13]. Although conventional urea increases nitrogen (N) content, its efficiency is low because $\mathrm{N}$ is only partially absorbed and utilized by plants $[13,14]$. The remaining $\mathrm{N}$ leaves the soil mainly via nitrification, volatilization, and leaching, which is harmful to the environment and has led to a series of agroecological issues [5,15]. Therefore, reducing fertilizer $\mathrm{N}$ loss and increasing its utilization efficiency are significant for sustainable agricultural development in the northeast region $[2,6,16]$.

Controlled release urea (CRU) is a new kind of urea that has less-soluble compounds coated the urea core, which enables nutrient release to ideally synchronize with the needs of crops [13]. 
CRU is considered to enhance crop yield while minimizing the nutrient losses to the environment, thereby alleviating negative environmental problems caused by the hazardous emissions $\left(\mathrm{NH}_{3}, \mathrm{~N}_{2} \mathrm{O}\right.$, etc.) [13,17-20]. However, there are minimal studies about the effects of CRU on the ratio of $\mathrm{NO}_{3}{ }^{-}$and $\mathrm{NH}_{4}{ }^{+}$in the soil [21]. Actually, the volatilization of $\mathrm{NH}_{3}$ is directly proportional to ammonium $\left(\mathrm{NH}_{4}{ }^{+}\right)$ concentration in the soil solution [21]. The formation of $\mathrm{N}_{2} \mathrm{O}$ is associated with high nitrate $\left(\mathrm{NO}_{3}{ }^{-}\right)$

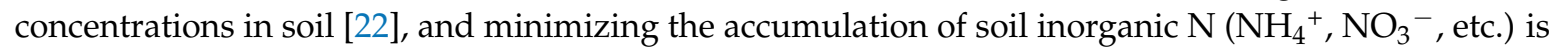
expected to reduce $\mathrm{N}_{2} \mathrm{O}$ emissions [23,24]. Thus, it is considerably important to study the accumulation of $\mathrm{NO}_{3}{ }^{-}$and $\mathrm{NH}_{4}{ }^{+}$in soil under different fertilization treatments for minimizing fertilizer $\mathrm{N}$ loss while maximizing its use efficiency $[25,26]$. The concentrations of $\mathrm{NO}_{3}{ }^{-}$and $\mathrm{NH}_{4}{ }^{+}$in soils are regulated by numerous factors, such as soil temperature, $\mathrm{pH}$, soil microbiology, fertilizer form, and moisture [27]. It was reported that high application rate of chemical $\mathrm{N}$ fertilizer significantly enhanced the amount of $\mathrm{NH}_{4}{ }^{+}{ }^{-15} \mathrm{~N}, \mathrm{NO}_{3}{ }^{-}{ }^{15} \mathrm{~N}$ in black soils of northeast China, compared to low $\mathrm{N}$ application rate [16]. But studies about the effects of CRU, compared with conventional urea, on the accumulation and kinetics of $\mathrm{NO}_{3}{ }^{-}$and $\mathrm{NH}_{4}{ }^{+}$in black soils of northeast China have not been reported.

In addition, the application of CRU in northeast China is limited by the lack of release kinetics in black soils because any changes in environmental conditions will make the release rate of CRU unpredictable [28]. For sustainable agricultural development in the northeast region, it is necessary to study the release kinetics of CRU in black soils. Although the release rate of CRU in soil has been commonly determined using the weight loss method [29-33], this method presents difficulty in completely separating the soil particles adsorbed on the surface of urea granules and is time-consuming to operate.

The one-month-long experiment using black soils with three $\mathrm{N}$ sources was conducted in an artificial climate chamber for the present study. The aims of this research were to (1) compare short-term effects of CRU and conventional urea on the ratio and kinetics of $\mathrm{NO}_{3}{ }^{-}$and $\mathrm{NH}_{4}{ }^{+}$and (2) investigate the kinetics of $\mathrm{N}$ release from $\mathrm{CRU}$ and correlations between the cumulative $\mathrm{N}$ release rate and concentrations of $\mathrm{NO}_{3}{ }^{-}$and $\mathrm{NH}_{4}{ }^{+}$in black soils. We hypothesized that (1) CRU could effectively decrease the accumulation of $\mathrm{NO}_{3}{ }^{-}$and $\mathrm{NH}_{4}{ }^{+}$and maintain the low $\mathrm{NO}_{3}{ }^{-} / \mathrm{NH}_{4}{ }^{+}$ratio in soil, compared to conventional urea, and (2) the $\mathrm{N}$ release would differ from CRU with two different coatings and concentrations of $\mathrm{NO}_{3}{ }^{-}$and $\mathrm{NH}_{4}{ }^{+}$could be selected to predict the cumulative $\mathrm{N}$ release rate.

\section{Materials and Methods}

\subsection{Test Materials}

Three kinds of urea were selected in this paper as the test fertilizers and are listed in Table 1.

Table 1. Basic information of tested fertilizers.

\begin{tabular}{cccc}
\hline Types & Labeled Nitrogen Content (\%) & Determined Nitrogen Content (\%) & Manufacturer \\
\hline conventional urea (U) & 46.2 & 46.85 & $\begin{array}{c}\text { Hanfeng Slow-Release Fertilizer } \\
\text { Co., Ltd. Shanghai, China }\end{array}$ \\
\hline $\begin{array}{c}\text { sulfur coated urea (SCU) } \\
\text { polyurethane coated } \\
\text { urea (PCU) }\end{array}$ & 37 & 39.78 & $\begin{array}{c}\text { Hanfeng Slow-Release Fertilizer } \\
\text { Co., Ltd. Shanghai, China }\end{array}$ \\
\hline
\end{tabular}

A vibrating sieve was used to separate fertilizer granules and select only those with diameters of $2 \sim 4 \mathrm{~mm}$ for the test sample. The tested soil was collected from Baishan City, Jilin Province, China, with a geographical location of East longitude $126^{\circ} 7^{\prime}$ to $128^{\circ} 18^{\prime}$ and North latitude $41^{\circ} 21^{\prime}$ to $42^{\circ} 48^{\prime}$. The basic physical and chemical properties of the soil are listed in Table 2 [34-39]. 
Table 2. Physical and chemical properties of soil.

\begin{tabular}{ccc}
\hline Basic Indicators & Values & Unit \\
\hline Organic matter & 538.64 & $\mathrm{~g} / \mathrm{kg}$ \\
Water content & 176.47 & $\mathrm{~g} / \mathrm{kg}$ \\
$\mathrm{pH}$ & 7.34 & $/$ \\
Conductivity $(\mathrm{EC})$ & 178.2 & $\mathrm{us} / \mathrm{cm}$ \\
Bulk density & 0.858 & $\mathrm{~g} / \mathrm{cm}^{3}$ \\
Porosity & 67.62 & $\%$ \\
Total nitrogen & 6427 & $\mathrm{mg} / \mathrm{kg}$ \\
\hline
\end{tabular}

Plastic pots with an upper diameter of $11.5 \mathrm{~cm}$, lower diameter of $10 \mathrm{~cm}$, and height of $9 \mathrm{~cm}$ were used in the experiment. Three treatments were performed with two parallel repeats for the urea group (U), sulfur-coated urea group (SCU), and polyurethane-coated urea group (PCU). The soil samples were mixed and sieved to $<2 \mathrm{~mm}$, and $1 \mathrm{~kg}$ of soil was placed into each plastic pot. The nitrogen application levels of all fertilization treatments were set to $500 \mathrm{mg} \cdot \mathrm{kg}^{-1}$ soil.

\subsection{Experimental Design}

The buried bag method was employed to determine the $\mathrm{N}$ release rate of the coated urea in soil $[29-33,40,41]$. The three kinds of urea were placed into $5 \times 5 \mathrm{~cm}$ polypropylene bags with 20 mesh cells, which were sealed and buried to a depth of $5 \sim 10 \mathrm{~cm}$ in the soil $[30,32,41]$. The experiment was carried out in an artificial climate chamber at a temperature of $(25 \pm 2){ }^{\circ} \mathrm{C}$, a humidity of $75 \%$, and in $33 \%$ visible light. Samples were collected after 7, 14, 21, 28, and 35 days. After the mesh bags were opened, coated urea granules were removed and rinsed with distilled water until the soil particles attached to the fertilizer were washed out, then absorbent paper was used to dry the fertilizer surface. The N release rates of the PCU and SCU were determined via the weight loss method [29-33]. CRU granules were dried at room temperature at least two weeks to a constant weight. Conventional urea was completely dissolved in the soil at the time of the first sampling, and all nitrogen was released. All soil in the pots was collected and mixed evenly after $2 \mathrm{~mm}$ sieve, which was stored at $-20^{\circ} \mathrm{C}$ for test. After extraction with potassium chloride solution, the concentrations of $\mathrm{NO}_{3}{ }^{-}$and $\mathrm{NH}_{4}{ }^{+}$ accumulation in soil were measured with a flow injection analyzer [42].

\subsection{Data Analysis Methods}

The average value was calculated for each treatment. Graphic drawing was performed using Originpro V.8.5 (OriginLab, Northampton, MA, USA) software. Correlation and regression analysis were performed using SPSS Statistics V.17.0 (SPSS, Chicago, IL, USA) and Matlab R2013a (MathWork Inc., Natick, MA, USA) software. The main evaluation parameters of the models include the Pearson correlation coefficient ( $\mathrm{r}$ ), the standard error (SE). For the binary linear regression model, the collinearity test was conducted using tolerance (T) and variance inflation factor (VIF).

\section{Results}

\subsection{Dynamics of Nitrate and Ammonium}

\subsubsection{Variation on the Ratio of Nitrate and Ammonium}

Figure 1 showed concentrations of $\mathrm{NO}_{3}{ }^{-}$and $\mathrm{NH}_{4}{ }^{+}$accumulation in the soil under three $\mathrm{N}$ sources.

As shown in Figure 1a, there was no significant difference between the concentration of $\mathrm{NO}_{3}{ }^{-}$ with U and SCU treatment in the soil, and both were higher than that of PCU during the experiment. The concentration of $\mathrm{NO}_{3}{ }^{-}$in the soil with three fertilization treatments increased gradually before 28 days where the performance of treatments occurred in the following order: U > SCU > PCU. 
$\mathrm{U}$ and PCU treatments decreased after 28 days, and SCU treatment continued to increase until it exceeded U. During the experiment, the accumulation of $\mathrm{NO}_{3}{ }^{-}$in the soil treated with PCU was significantly lower than that of $\mathrm{U}$ and SCU, which may be due to the fact that $\mathrm{N}$ release could be controlled by the polymer coating according to the crop demand. Concentrations of $\mathrm{NH}_{4}{ }^{+}$were substantially lower in soils amended with PCU and SCU compared with conventional urea, indicating the slower release of $\mathrm{N}$. The concentration of $\mathrm{NH}_{4}{ }^{+}$in the soil with $\mathrm{U}$ treatment plummeted in the early stages, followed by a slow drop till 28 days, which was consistent with previous studies. Then, the concentration of $\mathrm{NH}_{4}{ }^{+}$with $\mathrm{U}$ treatment showed an upward trend that was consistent with previous results. $\mathrm{NH}_{4}{ }^{+}$accumulation treated with $\mathrm{SCU}$ in black soils gradually declined and then stabilized, while the accumulation of $\mathrm{NH}_{4}{ }^{+}$treated with PCU increased slightly, which was consistent with previous results [43].

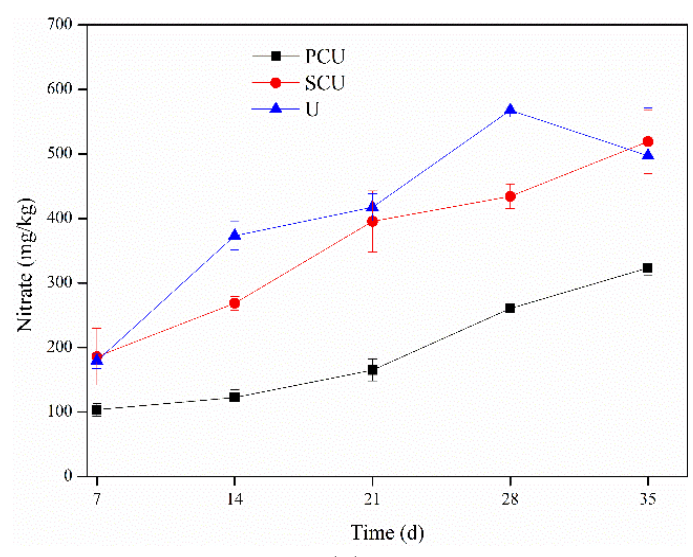

(a)

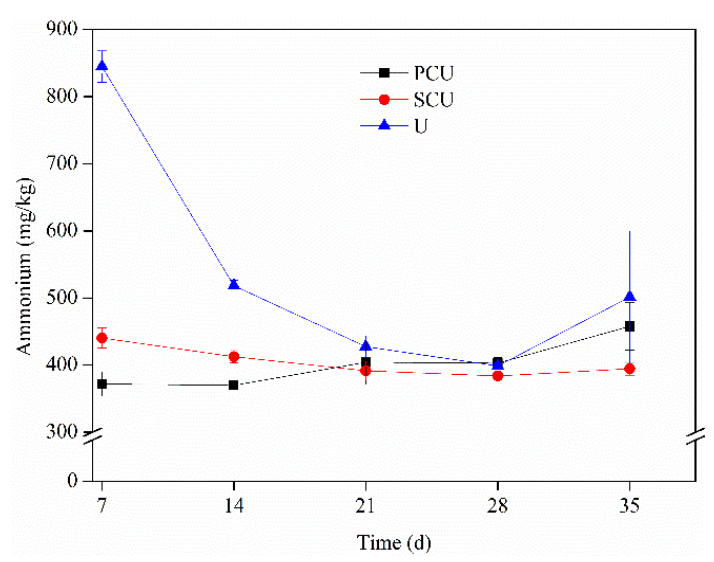

(b)

Figure 1. Dynamic changes of (a) nitrate and (b) ammonium in black soils.

Generally, the $\mathrm{NO}_{3}{ }^{-} / \mathrm{NH}_{4}{ }^{+}$ratio in soils with three $\mathrm{N}$ sources increased during the experiment, and the increasing rate with the application of PCU was lower than with the application of SCU and U (Figure 2). At early stages, the $\mathrm{NO}_{3}{ }^{-} / \mathrm{NH}_{4}{ }^{+}$ratios with three treatments were similar, all lower than 1.0. With time, the $\mathrm{NO}_{3}{ }^{-} / \mathrm{NH}_{4}{ }^{+}$ratios in the soils treated with $\mathrm{U}$ and $\mathrm{SCU}$ surpassed 1.0, while the ratio of the soil treated with PCU did not. Obviously, the $\mathrm{NO}_{3}{ }^{-} / \mathrm{NH}_{4}{ }^{+}$ratio in soils treated with PCU was lower than that in soils treated with $\mathrm{U}$ and SCU, which revealed that PCU was more effective in maintaining lower soil $\mathrm{NO}_{3}{ }^{-} / \mathrm{NH}_{4}{ }^{+}$ratios and more suitable for crop growth.

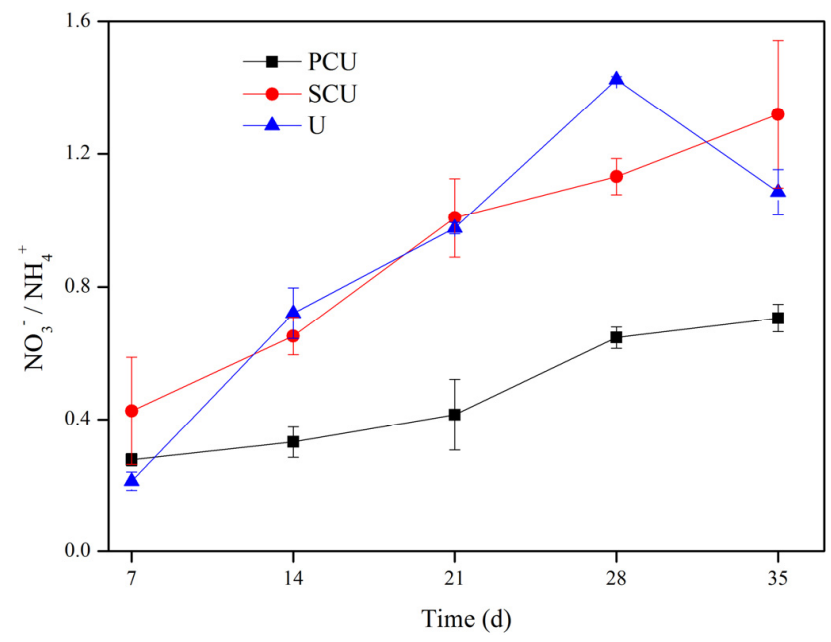

Figure 2. Dynamic changes of the $\mathrm{NO}_{3}{ }^{-} / \mathrm{NH}_{4}{ }^{+}$ratio. 


\subsubsection{Kinetics of Nitrate and Ammonium}

Dynamic parameters related to the $\mathrm{NO}_{3}{ }^{-}$and $\mathrm{NH}_{4}{ }^{+}$with three $\mathrm{N}$ sources were listed in Tables 3 and 4.

Table 3. Dynamic characteristics of $\mathrm{NO}_{3}{ }^{-}$in soil.

\begin{tabular}{ccccc}
\hline Treatment & Model & Equation & $\mathbf{r}$ & SE \\
\hline \multirow{3}{*}{$\mathrm{U}$} & First-order kinetic & $\mathrm{qt}=615.085\left(1-\mathrm{e}^{-0.06 \mathrm{t}}\right)$ & 0.952 & 46.36 \\
& Simple Elovich & $\mathrm{qt}=-33.493+220.584 \ln (\mathrm{t})$ & 0.950 & 50.73 \\
& Parabolic diffusion & $\mathrm{qt}=-63.984+106.174 \mathrm{t}^{0.5}$ & 0.926 & 59.58 \\
\hline \multirow{3}{*}{ PCU } & First-order kinetic & $\mathrm{qt}=332.770\left(1-\mathrm{e}^{-0.039 \mathrm{t}}\right)$ & 0.917 & 30.79 \\
& Simple Elovich & $\mathrm{qt}=-102.950+96.473 \ln (\mathrm{t})$ & 0.897 & 31.32 \\
& Parabolic diffusion & $\mathrm{qt}=-38.947+48.720 \mathrm{t}^{0.5}$ & 0.918 & 28.8 \\
\hline \multirow{3}{*}{$\mathrm{SCU}$} & First-order kinetic & $\mathrm{qt}=676.778\left(1-\mathrm{e}^{-0.040 \mathrm{t}}\right)$ & 0.939 & 54.47 \\
& Simple Elovich & $\mathrm{qt}=-235.365+205.318 \ln (\mathrm{t})$ & 0.950 & 47.22 \\
& Parabolic diffusion & $\mathrm{qt}=-93.994+102.525 \mathrm{t}^{0.5}$ & 0.926 & 57.53 \\
\hline
\end{tabular}

Significant at $p<0.05$.

Comparison of the values of Pearson correlation coefficients ( $r$ ) and the standard error (SE) of the first-order kinetic, Simple Elovich, and Parabolic diffusion equations showed that the $\mathrm{NO}_{3}{ }^{-}$ accumulation data were better fitted than $\mathrm{NH}_{4}{ }^{+}$. The high $\mathrm{r}$ value and smaller $\mathrm{SE}$ of the First-order kinetic equation showed better suitability of this equation for the $\mathrm{NO}_{3}{ }^{-}$accumulation in soil treated with U. Similarly, the parabolic diffusion and the simple Elovich equations described well the kinetics of $\mathrm{NO}_{3}{ }^{-}$accumulated in soil treated with PCU or SCU. Among three $\mathrm{N}$ sources, the parabolic diffusion equation with $\mathrm{U}$ treatment has the smallest $\mathrm{SE}$, indicating that the model has the highest accuracy.

Table 4. Dynamic characteristics of $\mathrm{NH}_{4}{ }^{+}$in soil.

\begin{tabular}{ccccc}
\hline Treatment & Model & Equation & r & SE \\
\hline \multirow{3}{*}{$\mathrm{U}$} & First-order kinetic & $/$ & $/$ & $/$ \\
& Simple Elovich & $\mathrm{qt}=1234.959-239.999 \ln (\mathrm{t})$ & 0.858 & 90.49 \\
& Parabolic diffusion & $\mathrm{qt}=1023.124-109.340 \mathrm{t}^{0.5}$ & 0.709 & 99.33 \\
\hline \multirow{3}{*}{ PCU } & First-order kinetic & $\mathrm{qt}=413\left(1-\mathrm{e}^{-0.302 \mathrm{t}}\right)$ & 0.537 & 21.13 \\
& Simple Elovich & $\mathrm{qt}=267.512+46.085 \ln (\mathrm{t})$ & 0.815 & 19.57 \\
& Parabolic diffusion & $\mathrm{qt}=294.295+24.128 \mathrm{t}^{0.5}$ & 0.866 & 17.95 \\
\hline \multirow{3}{*}{$\mathrm{SCU}$} & First-order kinetic & $/$ & $/$ & $/$ \\
& Simple Elovich & $\mathrm{qt}=500.964-33.184 \ln (\mathrm{t})$ & 0.932 & 8.798 \\
& Parabolic diffusion & $\mathrm{qt}=474.185-15.684 \mathrm{t}^{0.5}$ & 0.893 & 10.5 \\
\hline
\end{tabular}

Significant at $p<0.05$.

The kinetics of $\mathrm{NH}_{4}{ }^{+}$accumulation in black soils treated with $\mathrm{U}$ could not properly be described by these three kinetic equations because parameters $(r=0.858, \mathrm{SE}=90.49)$ were not significant. Similar to $\mathrm{NO}_{3}{ }^{-}$, the parabolic diffusion and the simple Elovich equations described well the kinetics of $\mathrm{NH}_{4}{ }^{+}$ accumulated in soil treated with PCU or SCU. Although the $r$ values of two equations for fitting $\mathrm{NH}_{4}{ }^{+}$were lower compared with equations for fitting $\mathrm{NO}_{3}{ }^{-}$, the smaller SE reflected the accuracy of equations used to describe the kinetics of $\mathrm{NH}_{4}{ }^{+}$was higher.

\subsection{Dynamics of Nitrogen Release from PCU and SCU}

\subsubsection{Characterization of Nitrogen Release}

In Figure 3, it is clear that the cumulative N release rate curves of controlled release urea with two different coatings were significantly different. 


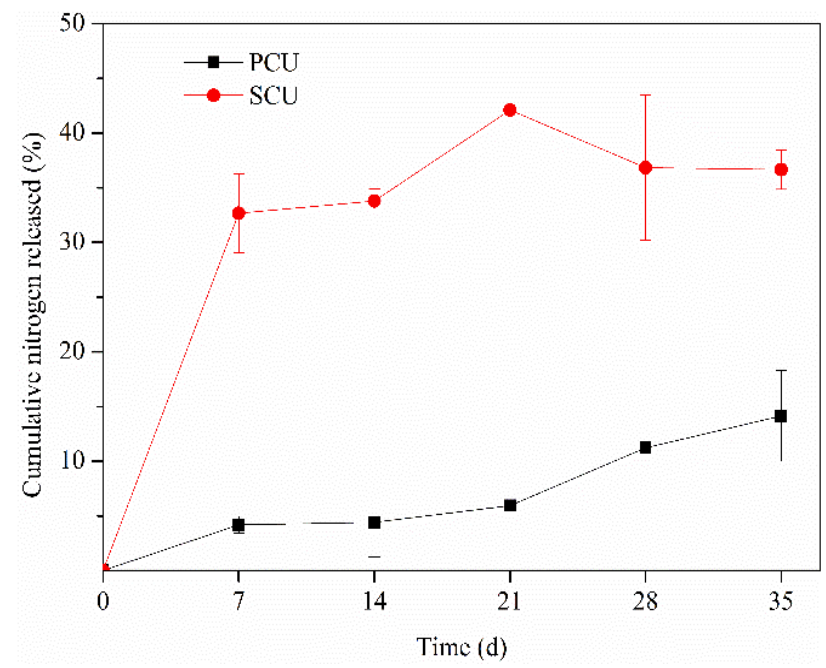

Figure 3. Nitrogen release from polyurethane-coated urea (PCU) and sulfur-coated urea (SCU).

At the beginning of the experiment, $\mathrm{N}$ release of SCU was faster than that of PCU. In the later stage, the cumulative release rate of SCU gradually stabilized, while PCU increased with a significantly higher growth trend than that of SCU. Initially in the experiment, the cumulative $\mathrm{N}$ release rate of SCU soared rapidly and was linearly released before the end of seven days. After that, the cumulative $\mathrm{N}$ release rate increased more slowly. By contrast, the cumulative $\mathrm{N}$ release rate of PCU increased steadily before 21 days, but the $\mathrm{N}$ was considered to release faster in later period because of the larger slope of the curve.

\subsubsection{Kinetics Analysis}

A number of kinetic equations have been used to study nutrients release characteristics of CRU. The parameters related to the frequently used equations are shown in Table 5.

Table 5. Kinetics equations, correlation coefficients (r), and standard errors (SE) of nitrogen release of PCU and SCU in soil.

\begin{tabular}{ccccc}
\hline Controlled Release Urea & Model & Equation & r & SE \\
\hline \multirow{2}{*}{ PCU } & First-order kinetic & $\mathrm{qt}=-15.829\left(1-\mathrm{e}^{0.018 \mathrm{t}}\right)$ & 0.946 & 1.671 \\
& Simple Elovich & $\mathrm{qt}=-20.2+6.001 \ln (\mathrm{t})$ & 0.854 & 2.683 \\
& Parabolic diffusion & $\mathrm{qt}=-5.98+3.146 \mathrm{t}^{0.5}$ & 0.907 & 2.171 \\
\hline \multirow{2}{*}{$\mathrm{SCU}$} & First-order kinetic & $\mathrm{qt}=37.76\left(1-\mathrm{e}^{-0.269 \mathrm{t}}\right)$ & 0.634 & 3.272 \\
& Simple Elovich & $\mathrm{qt}=26.64+3.364 \ln (\mathrm{t})$ & 0.584 & 3.434 \\
& Parabolic diffusion & $\mathrm{qt}=29.65+1.524 \mathrm{t}^{0.5}$ & 0.536 & 3.571 \\
\hline
\end{tabular}

Significant at $p<0.05$.

The relationship between the cumulative $\mathrm{N}$ release rate and time can be described using first-order kinetic, Elovich, and parabolic diffusion equations. Using the N release data of PCU and SCU (Figure 3), we compared the fitness of these equations. The highest $r$ value (0.946) and smallest SE (1.671) of the first-order kinetic equation among three equations showed best suitability for the release rate of $\mathrm{N}$ from the PCU. However, the highest $r$ value and smallest SE among equations for SCU were only 0.634 and 3.272, respectively, which indicated the three equations could not describe the $\mathrm{N}$ release well from SCU since the parameters were not remarkable enough.

\subsection{Correlation Analysis}

The correlation analysis between the cumulative $\mathrm{N}$ release rate of CRU and accumulation of $\mathrm{NO}_{3}{ }^{-}$and $\mathrm{NH}_{4}{ }^{+}$in black soils is shown in Figures 4 and 5 . 


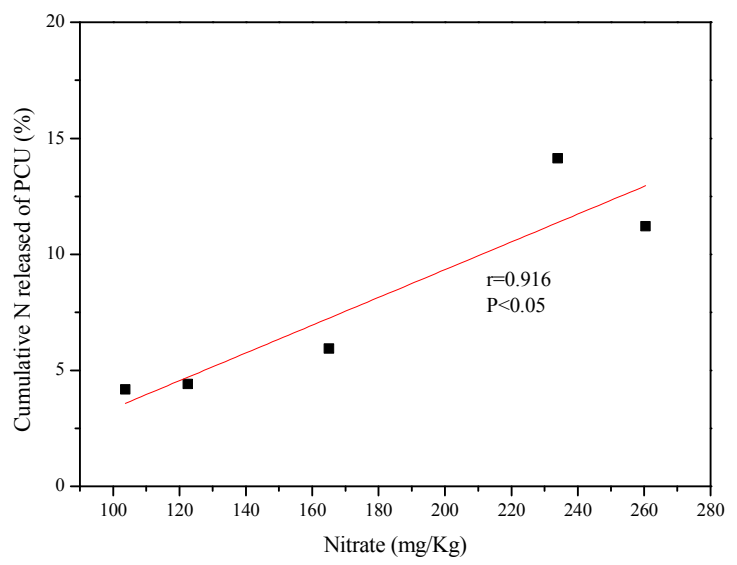

(a)

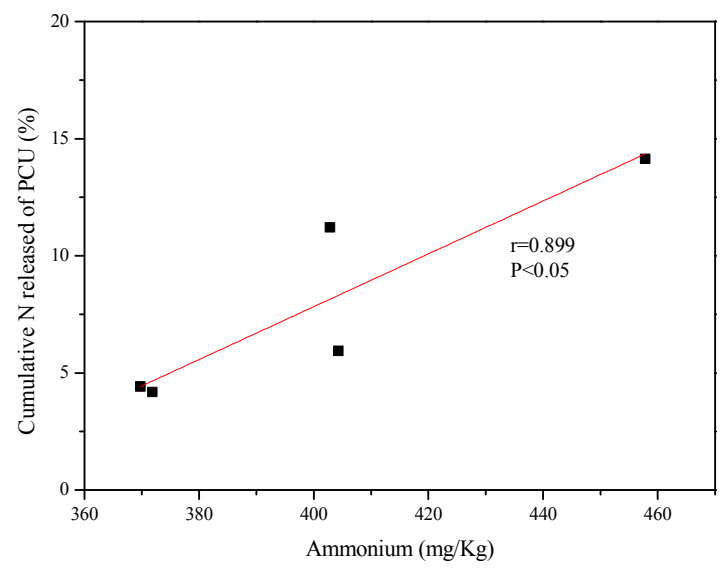

(b)

Figure 4. Correlation between cumulative nitrogen release rate of PCU and (a) nitrate and (b) ammonium in soil.

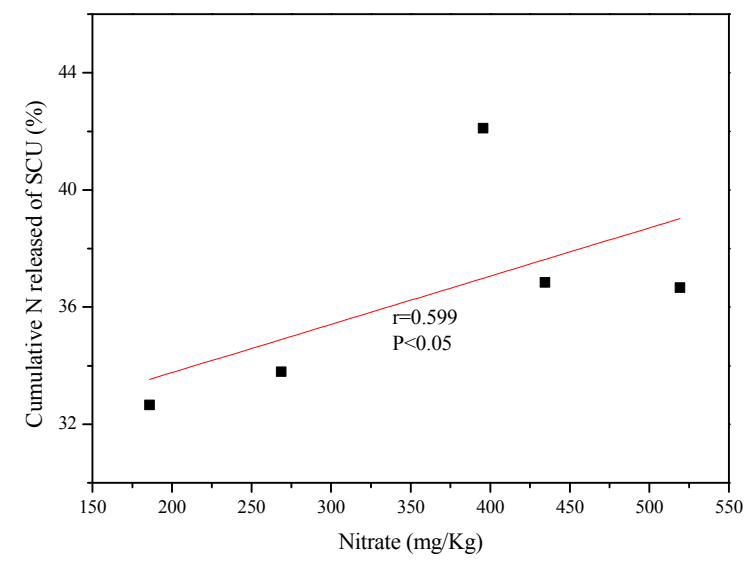

(a)

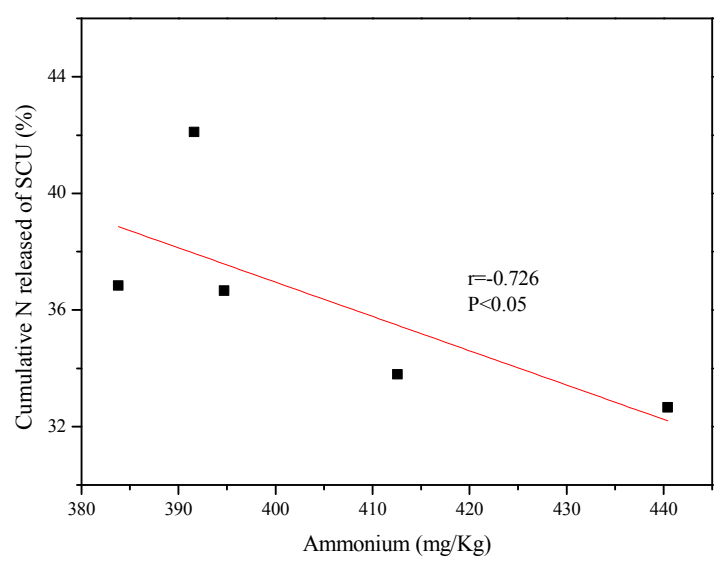

(b)

Figure 5. Correlation between cumulative nitrogen release rate of SCU and (a) nitrate and (b) ammonium in soil.

The cumulative $\mathrm{N}$ release rate of PCU was positively correlated with concentrations of $\mathrm{NO}_{3}{ }^{-}$and $\mathrm{NH}_{4}{ }^{+}$, and the correlation was significant after bilateral testing at the 0.05 level. Figure 5 showed the $\mathrm{N}$ release of $\mathrm{SCU}$ and $\mathrm{NO}_{3}{ }^{-}$did not have a strong correlation according to the $\mathrm{r}$ value, while the $\mathrm{N}$ release was negatively correlated with concentrations of $\mathrm{NH}_{4}{ }^{+}$after bilateral testing at the 0.05 level.

Based on correlation analysis results, $\mathrm{NO}_{3}{ }^{-}$and $\mathrm{NH}_{4}{ }^{+}$were selected as the binary variables in the predictive model of N release of PCU and SCU. The models and evaluation results were shown in the Table 6.

Table 6. Linear predictive models for predicting the $\mathrm{N}$ release of controlled release urea (CRU).

\begin{tabular}{|c|c|c|c|c|}
\hline \multirow{2}{*}{ Regression Equation } & \multicolumn{2}{|c|}{ Collinearity } & \multirow{2}{*}{$\mathbf{r}$} & \multirow{2}{*}{ SE } \\
\hline & $\mathbf{T}$ & VIF & & \\
\hline $\mathrm{PCU}=0.03618 \mathrm{~N}+0.06146 \mathrm{~A}-23.1$ & 0.454 & 2.203 & 0.973 & 1.449 \\
\hline SCU $=-0.004514 \mathrm{~N}-0.1409 \mathrm{~A}+95.06$ & 0.232 & 4.310 & 0.731 & 3.537 \\
\hline
\end{tabular}

Significant at $p<0.05$. Variance inflation factor (VIF).

The model with good fitness $(r=0.973, \mathrm{SE}=1.449)$ for PCU reflected the significance of $\mathrm{NO}_{3}{ }^{-}$ and $\mathrm{NH}_{4}{ }^{+}$in determination of cumulative $\mathrm{N}$ release rate in black soils, and it did not have collinearity 
problem. This model can effectively and quantitatively predict the $\mathrm{N}$ release of PCU in black soils through with the convenience and accuracy of data acquisition. Unfortunately, the $r$ value (0.731) and SE (3.537) of the model for SCU were not remark enough to further analysis and predict the $\mathrm{N}$ release of SCU. Although the model for predicting the N release of PCU had a better fitting degree, the model accuracy need to be improved by increasing the number of samples in further research.

\section{Discussion}

\subsection{Effects of CRU on Nitrate and Ammonium}

Studies have shown that any form of nitrogen from fertilizers that are applied to soil undergoes complex interactions with plant roots, soil microbes, chemical reactions, and loss pathways [21]. It has been reported that $\mathrm{NH}_{4}{ }^{+}$is converted to $\mathrm{NO}_{2}{ }^{-}$by the oxidation of nitrite bacteria, and $\mathrm{NO}_{2}{ }^{-}$is easily oxidized to $\mathrm{NO}_{3}{ }^{-}$by nitrified bacteria [44]. $\mathrm{NO}_{3}{ }^{-}$in high concentration can be leached or transferred from the zone near plant roots to surface water or groundwater [21,45-47], while the remaining $\mathrm{NO}_{3}{ }^{-}$under hypoxia conditions is denitrified into $\mathrm{N}_{2}, \mathrm{NO}$, and $\mathrm{N}_{2} \mathrm{O}$, which are then dispersed into the atmosphere [17]. It was reported that the concentration of $\mathrm{NH}_{4}{ }^{+}$decreased sharply during the incubation period from 10 to 15 days with the application of fertilizer-N [48], which could be due to the loss of $\mathrm{NH}_{3}$ by volatilization or transformation of $\mathrm{NH}_{4}{ }^{+}$to $\mathrm{NO}_{3}{ }^{-}$by nitrification $[17,43]$. It could be concluded from Figure 1, to some extent, CRU is beneficial in reducing the adverse effects caused by residual $\mathrm{N}$ that are not fully utilized after fertilization and transferred through various routes into the environment $[13,49]$.

Generally, the $\mathrm{NO}_{3}{ }^{-} / \mathrm{NH}_{4}{ }^{+}$ratio in soils with three $\mathrm{N}$ sources increased during the experiment (Figure 2), consistent with the results of previous studies [48], perhaps because $\mathrm{NH}_{4}{ }^{+}$was readily converted to $\mathrm{NO}_{3}{ }^{-}$by microorganisms [50]. $\mathrm{NO}_{3}{ }^{-}$and $\mathrm{NH}_{4}{ }^{+}$play an important role in plant growth and seed yield [51]. Lower ratios of $\mathrm{NO}_{3}{ }^{-} / \mathrm{NH}_{4}{ }^{+}$was important for uptake of $\mathrm{N}$ [50], and could promote vegetative growth rate of plants and floral tiller number [52], as well as increase cereal yields [53]. Fertilizer $\mathrm{N}$ source was available to obtain and maintain relatively low soil $\mathrm{NO}_{3}{ }^{-} / \mathrm{NH}_{4}{ }^{+}$ ratios $[50,53,54]$. In addition, the ratio of $\mathrm{NO}_{3}{ }^{-} / \mathrm{NH}_{4}{ }^{+}$was used as indicators of nitrification inhibition effectiveness [48], a further indication that nitrification was slower with PCU treatment than with SCU and $\mathrm{U}$ throughout the study period.

Several equations have been reported to fit and model the release of $\mathrm{NO}_{3}{ }^{-}$and $\mathrm{NH}_{4}{ }^{+}$with time. Among them, three equations, including the first-order kinetics equation, parabolic diffusion equation, and simple Elovich equation, have been frequently used to study kinetics of $\mathrm{NO}_{3}{ }^{-}$and $\mathrm{NH}_{4}{ }^{+}$ accumulation especially in calcareous soils $[55,56]$. Parabolic diffusion and simple Elovich equations were reported to describe very well the kinetics of $\mathrm{K}$ release from calcareous soils [56]. Because $\mathrm{NH}_{4}{ }^{+}$ and $\mathrm{K}^{+}$were considered to behave the same in soils [55], these two equations were also selected to study the release kinetics of $\mathrm{NH}_{4}{ }^{+}$in calcareous soils and the simple Elovich equation was regarded to fit well the release of $\mathrm{NH}_{4}{ }^{+}$[55]. $\mathrm{N}$ fertilizer application as one of factors affecting $\mathrm{NH}_{4}{ }^{+}$concentration in soil solution may control the release of $\mathrm{NH}_{4}{ }^{+}$[55], thus the fate of $\mathrm{NH}_{4}{ }^{+}$after the application of conventional urea and CRU has been discussed in this paper.

\subsection{Characterization and Prediction of Nitrogen Release from CRU in Black Soils}

$\mathrm{N}$ was released more steadily from PCU than from SCU, indicating that PCU had better controlled release properties of $\mathrm{N}$ [57-59]. Other studies have shown that the $\mathrm{N}$ release profile of PCU in the soil could be inferred from the $\mathrm{N}$ released in water at $25^{\circ} \mathrm{C}[44,60]$. It has also been shown that SCU granules release urea in the soil faster than in solution [60]. The release of $\mathrm{N}$ in the later stage of the experiment tended to be gentle, which is mainly due to the fact that SCU is controlled by the micropores and cracks in the sulfur coating. Water entered the membrane to dissolve the fertilizer and form a solution, causing the internal pressure of the coated granules to increase. The sulfur shell then ruptured due to its brittleness and inelasticity, leading to rapid release of urea in the short 
term and slight insufficiency of $\mathrm{N}$ supply later in the experiment $[60,61]$. Although the cumulative $\mathrm{N}$ release rates of CRU did not reach $100 \%$ at the end of the experiment, the results could be used to characterize the patterns of the $\mathrm{N}$ release in black soils from CRU like previous studies [62-65]. The relationship between the cumulative $\mathrm{N}$ release rate and time can be described using first-order kinetic, Elovich, and parabolic diffusion equations [66-68]. Using the N release data of PCU and SCU (Figure 3), we compared the fitness of these equations. The highest $r$ value (0.946) and smallest SE (1.671) of the First-order kinetic equation among three equations showed best suitability for the release rate of $\mathrm{N}$ from the PCU $[69,70]$. The first-order kinetic equation was established to predict $\mathrm{N}$ release from resin-coated urea in a typical cinnamon soil [71], and it was also used to describe slow-release mechanism of $\mathrm{N}$ from organic-inorganic compound-coated urea [67]. However, the fitness of three equations $(0.536<\mathrm{r}<0.634)$ for SCU was poor mainly because the $\mathrm{N}$ release from SCU is controlled by rupture mechanism, while the $\mathrm{N}$ release from polymer coating is affected by diffusion $[13,28]$.

Controlled release urea (CRU) was widely reported to increase crop yields while reducing the nitrogen loss and increasing its utilization efficiency $[13,17-20]$, which is very important for the sustainable development of the environment in northeast China. However, studies about the application of CRF in black soil regions are very limited. Correlation analysis results were conducive to study effects of CRU on reducing environmental pollution in the northeast China. Based on predictive models of $\mathrm{N}$ release from PCU, we could study the $\mathrm{N}$ release from PCU in black soils by determining the concentrations of $\mathrm{NO}_{3}{ }^{-}$and $\mathrm{NH}_{4}{ }^{+}$instead of the weight loss method [29-33]. However, we need to improve the accuracy by increasing the number of samples in further research.

\section{Conclusions}

CRU can reduce concentrations of $\mathrm{NO}_{3}{ }^{-}$and $\mathrm{NH}_{4}{ }^{+}$accumulation in black soils, thereby reducing harmful gas emissions, compared with conventional urea. PCU was more effective in maintaining lower soil $\mathrm{NO}_{3}{ }^{-} / \mathrm{NH}_{4}{ }^{+}$ratios, indicating that nitrification was slower with PCU treatment, which meant PCU was more suitable for crop growth than SCU and U. The kinetics of $\mathrm{NO}_{3}{ }^{-}$accumulation in black soils treated with $U$ was best described by the first-order kinetics equation, while the three kinetic equations were not suitable for describing the kinetics of $\mathrm{NH}_{4}{ }^{+}$. Parabolic diffusion equation could fit the kinetics of $\mathrm{NO}_{3}{ }^{-}$and $\mathrm{NH}_{4}{ }^{+}$accumulation treated with PCU. Simple Elovich equation could fit the kinetics of $\mathrm{NO}_{3}{ }^{-}$and $\mathrm{NH}_{4}{ }^{+}$accumulation treated with $\mathrm{SCU}$. The relationship between cumulative $\mathrm{N}$ release rate of PCU and time could be described best by the first-order kinetics equation, followed by parabolic diffusion equation, and then the simple Elovich equation. However, the kinetics of $\mathrm{N}$ release from SCU could not be described well by these three equations. Significant correlations were found between the $\mathrm{N}$ release rate of $\mathrm{PCU}$ and concentrations of $\mathrm{NO}_{3}{ }^{-}$and $\mathrm{NH}_{4}{ }^{+}$in black soils, so the binary linear regression model was established to predict $\mathrm{N}$ release from PCU. These results were conducive to study effects of CRU on reducing environmental pollution in the northeast China caused by the application of excessive fertilizer, and provided a methodology and data support for characterizing and predicting the N release from PCU in black soils.

Acknowledgments: This work was financially supported by the Program for Changjiang Scholars and Innovative Research Team in University (Project No. IRT1293), the National Key Technology Support Program of China (Grant number 2015BAC02B02-02), and the National Key Research and Development Program of China (Grant number 2016YFE0112800).

Author Contributions: X.T., G.H., and L.H. conceived and designed the experiments; X.T. performed the experiments; X.T. and X.H. analyzed the data; X.H. and W.D. contributed analysis tools; X.T. wrote the paper.

Conflicts of Interest: The authors declare no conflict of interest. 


\section{References}

1. Liu, X.; Burras, C.L.; Kravchenko, Y.S.; Duran, A.; Huffman, T.; Morras, H.; Studert, G.; Zhang, X.; Cruse, R.M.; Yuan, X. Overview of Mollisols in the world: Distribution, land use and management. Can. J. Soil Sci. 2012, 92, 383-402. [CrossRef]

2. Hu, G.; Wu, Y.; Liu, B.; Yu, Z.; You, Z.; Zhang, Y. Short-term gully retreat rates over rolling hill areas in black soil of Northeast China. Catena 2007, 71, 321-329. [CrossRef]

3. Xu, X.Z.; Xu, Y.; Chen, S.C.; Xu, S.G.; Zhang, H.W. Soil loss and conservation in the black soil region of Northeast China: A retrospective study. Environ. Sci. Policy 2010, 13, 793-800. [CrossRef]

4. Song, G.; Zhou, C.; Wang, Y. Calculation of county cultivated land productivity and its analysis of influential factors of grain main production area in Northeast China. Trans. Chin. Soc. Agric. Eng. 2014, 30, 308-317.

5. Ding, J.; Jiang, X.; Ma, M.; Zhou, B.; Guan, D.; Zhao, B.; Zhou, J.; Cao, F.; Li, L.; Li, J. Effect of 35 years inorganic fertilizer and manure amendment on structure of bacterial and archaeal communities in black soil of northeast China. Appl. Soil Ecol. 2016, 105, 187-195. [CrossRef]

6. Ma, Q.; Yu, W.-T.; Zhao, S.-H.; Zhang, L. Relationship between Water-Stable Aggregates and Nutrients in Black Soils after Reclamation. Pedosphere 2007, 17, 538-544. [CrossRef]

7. Akelah, A. Novel utilizations of conventional agrochemicals by controlled release formulations. Mater. Sci. Eng. C 1996, 4, 83-98. [CrossRef]

8. Singh, S.; Ghoshal, N.; Singh, K.P. Synchronizing nitrogen availability through application of organic inputs of varying resource quality in a tropical dryland agroecosystem. Appl. Soil Ecol. 2007, 36, 164-175. [CrossRef]

9. Kong, W.-D.; Zhu, Y.-G.; Fu, B.-J.; Han, X.-Z.; Zhang, L.; He, J.-Z. Effect of Long-Term Application of Chemical Fertilizers on Microbial Biomass and Functional Diversity of a Black Soil. Pedosphere 2008, 18, 801-808. [CrossRef]

10. Qiao, D.; Liu, H.; Yu, L.; Bao, X.; Simon, G.P.; Petinakis, E.; Chen, L. Preparation and characterization of slow-release fertilizer encapsulated by starch-based superabsorbent polymer. Carbohydr. Polym. 2016, 147, 146-154. [CrossRef] [PubMed]

11. Papangkorn, J.; Isaraphan, C.; Phinhongthong, S.; Opaprakasit, M.; Opaprakasit, P. Controlled-release material for urea fertilizer from polylactic acid. Adv. Mater. Res. 2008, 55, 897-900. [CrossRef]

12. Zheng, T.; Liang, Y.; Ye, S.; He, Z. Superabsorbent hydrogels as carriers for the controlled-release of urea: Experiments and a mathematical model describing the release rate. Biosyst. Eng. 2009, 102, 44-50. [CrossRef]

13. Trenkel, M.E. Slow-and Controlled-Release and Stabilized Fertilizers: An Option for Enhancing Nutrient Use Efficiency in Agriculture; International Fertilizer Industry Association (IFA): Paris, France, 2010.

14. Shaviv, A. Advances in controlled-release fertilizers. Adv. Agron. 2001, 71, 1-49.

15. Naz, M.Y.; Sulaiman, S.A.; Ariwahjoedi, B.; Shaari, K.Z.K. Characterization of modified tapioca starch solutions and their sprays for high temperature coating applications. Sci. World J. 2014, 2014, 375206. [CrossRef] [PubMed]

16. Lu, C.; Zhang, X.; Chen, X.; Shi, Y.; Ma, J.; Zhao, M.; Chi, G.; Huang, B. Fixation of labeled $\left({ }^{15} \mathrm{NH}_{4}\right)_{2} \mathrm{SO}_{4}$ and its subsequent release in black soil of Northeast China over consecutive crop cultivation. Soil Tillage Res. 2010, 106, 329-334. [CrossRef]

17. Dave, A.M.; Mehta, M.H.; Aminabhavi, T.M.; Kulkarni, A.R.; Soppimath, K.S. A review on controlled release of nitrogen fertilizers through polymeric membrane devices. Polym.-Plast. Technol. Eng. 1999, 38, 675-711. [CrossRef]

18. Wu, S.; Mickley, L.J.; Jacob, D.J.; Rind, D.; Streets, D.G. Effects of 2000-2050 changes in climate and emissions on global tropospheric ozone and the policy-relevant background surface ozone in the United States. J. Geophys. Res. Atmos. 2008, 113. [CrossRef]

19. Bortoletto-Santos, R.; Ribeiro, C.; Polito, W.L. Controlled release of nitrogen-source fertilizers by natural-oil-based poly (urethane) coatings: The kinetic aspects of urea release. J. Appl. Polym. Sci. 2016, 133. [CrossRef]

20. Liu, Q.; Chen, Y.; Liu, Y.; Wen, X.; Liao, Y. Coupling effects of plastic film mulching and urea types on water use efficiency and grain yield of maize in the Loess Plateau, China. Soil Tillage Res. 2016, 157, 1-10. [CrossRef]

21. Shaviv, A.; Mikkelsen, R.L. Controlled-release fertilizers to increase efficiency of nutrient use and minimize environmental degradation-A review. Nutr. Cycl. Agroecosyst. 1993, 35, 1-12. [CrossRef]

22. Jenkinson, D.S. An introduction to the global nitrogen cycle. Soil Use Manag. 1990, 6, 56-61. [CrossRef] 
23. Firestone, M.K.; Davidson, E.A. Microbiological basis of $\mathrm{NO}$ and $\mathrm{N}_{2} \mathrm{O}$ production and consumption in soil. Exch. Trace Gases Terr. Ecosyst. Atmos. 1989, 47, 7-21.

24. Zhang, W.; Zhou, G.; Li, Q.; Liao, N.; Guo, H.; Min, W.; Ma, L.; Ye, J.; Hou, Z. Saline water irrigation stimulate $\mathrm{N}_{2} \mathrm{O}$ emission from a drip-irrigated cotton field. Acta Agric. Scand. 2016, 66, 141-152. [CrossRef]

25. Angás, P.; Lampurlanés, J.; Cantero-Martínez, C. Tillage and $\mathrm{N}$ fertilization: Effects on $\mathrm{N}$ dynamics and barley yield under semiarid Mediterranean conditions. Soil Tillage Res. 2006, 87, 59-71. [CrossRef]

26. Lu, C.Y.; Zhang, Q.Z.; Zhao, M.Q.; Shi, Y.; Chen, X. Accumulation and profile distribution of soil mineralized nitrogen in fallow season. Commun. Soil Sci. Plan. 2008, 39, 707-714. [CrossRef]

27. Schmidt, E.L. Nitrification in soil. Nitrogen Agric. Soils 1982, 22, 253-288.

28. Azeem, B.; KuShaari, K.; Man, Z.B.; Basit, A.; Thanh, T.H. Review on materials \& methods to produce controlled release coated urea fertilizer. J. Control. Release 2014, 181, 11-21. [PubMed]

29. Wilson, M.L.; Rosen, C.J.; Moncrief, J.F. A comparison of techniques for determining nitrogen release from polymer-coated urea in the field. HortScience 2009, 44, 492-494.

30. Hyatt, C.R.; Venterea, R.T.; Rosen, C.J.; McNearney, M.; Wilson, M.L.; Dolan, M.S. Polymer-coated urea maintains potato yields and reduces nitrous oxide emissions in a Minnesota loamy sand. Soil Sci. Soc. Am. J. 2010, 74, 419-428. [CrossRef]

31. Yang, Y.C.; Zhang, M.; Zheng, L.; Cheng, D.D.; Liu, M.; Geng, Y.Q. Controlled release urea improved nitrogen use efficiency, yield, and quality of wheat. Agron. J. 2011, 103, 479-485. [CrossRef]

32. Yang, Y.; Zhang, M.; Zheng, L.; Cheng, D.; Liu, M.; Geng, Y.; Chen, J. Controlled-release urea for rice production and its environmental implications. J. Plant Nutr. 2013, 36, 781-794. [CrossRef]

33. Geng, J.; Chen, J.; Sun, Y.; Zheng, W.; Tian, X.; Yang, Y.; Li, C.; Zhang, M. Controlled release urea improved nitrogen use efficiency and yield of wheat and corn. Agron. J. 2016, 108, 1666-1673. [CrossRef]

34. Ministry of Environmental Protection of the People's Republic of China. National Environmental Protection Standards of the People's Republic of China. HJ 717-2014; Ministry of Environmental Protection of the People's Republic of China: Beijing, China, 2014.

35. Ministry of Environmental Protection of the People's Republic of China. National Environmental Protection Standards of the People's Republic of China. HJ 634-2012; Ministry of Environmental Protection of the People's Republic of China: Beijing, China, 2012.

36. Ministry of Environmental Protection of the People's Republic of China. National Environmental Protection Standards of the People's Republic of China. HJ 613-2011; Ministry of Environmental Protection of the People's Republic of China: Beijing, China, 2011.

37. Ministry of Environmental Protection of the People's Republic of China. National Environmental Protection Standards of the People's Republic of China. HJ 802-2016; Ministry of Environmental Protection of the People's Republic of China: Beijing, China, 2016.

38. Ministry of Agriculture of the People's Republic of China. Agricultural Industry Standard of the People's Republic of China. NYT 1121.4-2006; Ministry of Agriculture of the People's Republic of China: Beijing, China, 2006.

39. Ministry of Agriculture of the People's Republic of China. Agricultural Industry Standard of the People's Republic of China. NYT 1377-2007; Ministry of Agriculture of the People's Republic of China: Beijing, China, 2007.

40. Wilson, M.L.; Rosen, C.J.; Moncrief, J.F. Effects of polymer-coated urea on nitrate leaching and nitrogen uptake by potato. J. Agric. Food Chem. 2010, 39, 492-499. [CrossRef] [PubMed]

41. Yang, Y.; Tong, Z.; Geng, Y.; Li, Y.; Zhang, M. Biobased polymer composites derived from corn stover and feather meals as double-coating materials for controlled-release and water-retention urea fertilizers. J. Agric. Food Chem. 2013, 61, 8166-8174. [CrossRef] [PubMed]

42. Maharjan, B.; Venterea, R.T. Nitrite intensity explains $\mathrm{N}$ management effects on $\mathrm{N}_{2} \mathrm{O}$ emissions in maize. Soil Biol. Biochem. 2013, 66, 229-238. [CrossRef]

43. Paramasivam, S.; Alva, A.K. Leaching of nitrogen forms from controlled-release nitrogen fertilizers. Commun. Soil Sci. Plan. 1997, 28, 1663-1674. [CrossRef]

44. Lunt, O.R. Modified sulphur coated granular urea for controlled nutrient release. Int. Soc. Soil Sci. Trans. 1968, 3, 337-383.

45. Kuhlmann, H.; Engels, T. Nitrogen Utilisation in Relation to N-Fertilisation; Fertiliser Society: Colchester, UK, 1989. 
46. Smith, S.J.; Schepers, J.S.; Porter, L.K. Assessing and managing agricultural nitrogen losses to the environment. In Advances in Soil Science; Springer: New York, NY, USA, 1990; pp. 1-43.

47. $\mathrm{Xu}, \mathrm{J}$; Liao, L.; Tan, J.; Shao, X. Ammonia volatilization in gemmiparous and early seedling stages from direct seeding rice fields with different nitrogen management strategies: A pots experiment. Soil Tillage Res. 2013, 126, 169-176. [CrossRef]

48. Aulakh, M.S.; Kuldipsingh, D.J. Effects of 4-amino 1, 2, 4-triazole, dicyandiamide and encapsulated calcium carbide on nitrification inhibition in a subtropical soil under upland and flooded conditions. Biol. Fertil. Soils 2001, 33, 258-263. [CrossRef]

49. Naz, M.Y.; Sulaiman, S.A. Slow release coating remedy for nitrogen loss from conventional urea: A review. J. Control. Release 2016, 225, 109-120. [CrossRef] [PubMed]

50. Barber, K.L.; Maddux, L.D.; Pierzynski, G.M.; Kissel, D.E.; Bock, B.R. Corn responses to ammonium-and nitrate-nitrogen fertilization. Soil Sci. Soc. Am. J. 1992, 56, 1166-1171. [CrossRef]

51. Griffith, S.M.; Alderman, S.C.; Streeter, D.J. Italian ryegrass and nitrogen source fertilization in western Oregon in two contrasting climatic years. II. Plant nitrogen accumulation and soil nitrogen status. J. Plant Nutr. 1997, 20, 429-439. [CrossRef]

52. Griffith, S.M.; Streeter, D.J. Nitrate and ammonium nutrition in ryegrass: Changes in growth and chemical composition under hydroponic conditions. J. Plant Nutr. 1994, 17, 71-81. [CrossRef]

53. Bock, B.R. Increasing cereal yields with higher ammonium/nitrate ratios: Review of potentials and limitations. J. Environ. Sci. Health A 1986, 21, 723-758. [CrossRef]

54. Pan, W.L.; Kamprath, E.J.; Moll, R.H.; Jackson, W.A. Prolificacy in corn: Its effects on nitrate and ammonium uptake and utilization. Soil Sci. Soc. Am. J. 1984, 48, 1101-1106. [CrossRef]

55. Ranjbar, F.; Jalali, M. Empirical and Mechanistic Evaluation of $\mathrm{NH}_{4}{ }^{+}$Release Kinetic in Calcareous Soils. Arch. Environ. Contam. Toxicol. 2014, 66, 606-615. [CrossRef] [PubMed]

56. Najafi-Ghiri, M. Effects of zeolite and vermicompost applications on potassium release from calcareous soils. Soil Water Res. 2014, 9, 31-37.

57. Yang, Y.C.; Zhang, M.; Li, Y.; Fan, X.H.; Geng, Y.Q. Improving the quality of polymer-coated urea with recycled plastic, proper additives, and large tablets. J. Agric. Food Chem. 2012, 60, 11229-11237. [CrossRef] [PubMed]

58. Lu, P.; Zhang, M.; Li, Q.; Xu, Y. Structure and properties of controlled release fertilizers coated with thermosetting resin. Polym. Plast. Technol. 2013, 52, 381-386. [CrossRef]

59. Lu, P.; Zhang, Y.; Jia, C.; Li, Y.; Mao, Z. Use of polyurea from urea for coating of urea granules. SpringerPlus 2016, 5, 457. [CrossRef] [PubMed]

60. Jarrell, W.M.; Boersma, L. Release of urea by granules of sulfur-coated urea. Soil Sci. Soc. Am. J. 1980, 44, 418-422. [CrossRef]

61. Jarrell, W.M.; Boersma, L. Model for the release of urea by granules of sulfur-coated urea applied to soil. Soil Sci. Soc. Am. J. 1979, 43, 1044-1050. [CrossRef]

62. Du, C.; Zhou, J.; Shaviv, A. Release characteristics of nutrients from polymer-coated compound controlled release fertilizers. J. Polym. Environ. 2006, 14, 223-230. [CrossRef]

63. Liang, R.; Liu, M.; Wu, L. Controlled release NPK compound fertilizer with the function of water retention. React. Funct. Polym. 2007, 67, 769-779. [CrossRef]

64. Dai, J.J.; Fan, X.L.; Yu, J.G.; Fang, L.I.U.; Zhang, Q. Study on the rapid method to predict longevity of controlled release fertilizer coated by water soluble resin. Agric. Sci. China 2008, 7, 1127-1132. [CrossRef]

65. Thiex, N. Determination of nitrogen, phosphorus, and potassium release rates of slow-and controlled-release fertilizers: Single-laboratory validation, first action 2015. 15. J. AOAC Int. 2016, 99, 353-359. [CrossRef] [PubMed]

66. Xiong, Y.S.; Yuan, J.F.; Hu, R.G. Characteristics of nutrient release kinetics for organic polymer-coated fertilizers. J. Food Agric. Environ. 2010, 8, 733-735.

67. Zou, H.; Ling, Y.; Dang, X.; Yu, N.; Zhang, Y.; Zhang, Y.; Dong, J. Solubility characteristics and slow-release mechanism of nitrogen from organic-inorganic compound coated urea. Int. J. Photoenergy 2015, 2015, 705471. [CrossRef]

68. Kundu, S.; Adhikari, T.; Coumar, M.V.; Rajendiran, S.; Bhattacharyya, R.; Saha, J.K.; Biswas, A.K.; Rao, A.S. Pine oleoresin: A potential urease inhibitor and coating material for slow-release urea. Curr. Sci. India 2013, $104,1068-1071$. 
69. Zhang, M.; Nyborg, M.; Malhi, S.S.; McKenzie, R.H.; Solberg, E. Phosphorus release from coated monoammonium phosphate: Effect of coating thickness, temperature, elution medium, soil moisture and placement method. Can. J. Soil Sci. 2000, 80, 127-134. [CrossRef]

70. He, Z.L.; Baligar, V.C.; Martens, D.C.; Ritchey, K.D.; Elrashidi, M. Effect of byproduct, nitrogen fertilizer, and zeolite on phosphate rock dissolution and extractable phosphorus in acid soil. Plant Soil 1999, 208, 199-207. [CrossRef]

71. Xiao, Q.; Fan, X.; Ni, X.; Li, L.; Zou, G.; Cao, B. Predicting Nitrogen Release from Parabolic-type Resin-coated Urea in Greenhouse Tomato and Cucumber Production. HortScience 2017, 52, 1013-1019. [CrossRef]

(C) 2018 by the authors. Licensee MDPI, Basel, Switzerland. This article is an open access article distributed under the terms and conditions of the Creative Commons Attribution (CC BY) license (http://creativecommons.org/licenses/by/4.0/). 